\title{
Solar DER Investment for MWANI Qatar Building at Hamad Port
}

\author{
Adel Karama \\ adelkarama@gmail.com \\ EllisDon Q, Doha, Qatar
}

\begin{abstract}
This document discusses the benefits of adding a solar distributed energy resource (DER) investment to MWANI Qatar (MQ) building at Hamad Port. The social and environmental aspects of a Solar PV system with battery storage were evaluated besides economic calculations outcome. The calculations show a marvelous $96 \% \mathrm{CO} 2$ emission reduction with significant battery storage benefits and a $269,676 \mathrm{KWh} / \mathrm{yr}$ reduction in electricity leading to a $\$ 33,217.52$ annual savings. In essence, the State of Qatar is governed by a vision of excellence, innovation and leadership that this investment could be a role model for the country's sustainable future developments.
\end{abstract}

Keywords: Solar battery; Construction; Distributed energy resource (DER)

\section{INTRODUCTION}

Hamad Port Project(HPP) is of one of the world's largest Greenfield port developments. Strategically located south of Doha covering 28 square kilometers with a budget of USD \$7.4 Billion (New Port Project Steering Committee). It is a megaproject that includes a new port, a new base for the Qatar Emiri Naval Forces and the Qatar Economic Zone (3). The port is managed by MWANI Qatar (MQ), which is in charge for handling Qatar's shipping terminals and seaports. The port contains three iconic buildings that were designed to reflect the advancement technology of the port. One of those iconic buildings is MQ building as shown in Figure 1(MwaniQatar) which is referred to as the "cheese building" due to its triangular design.

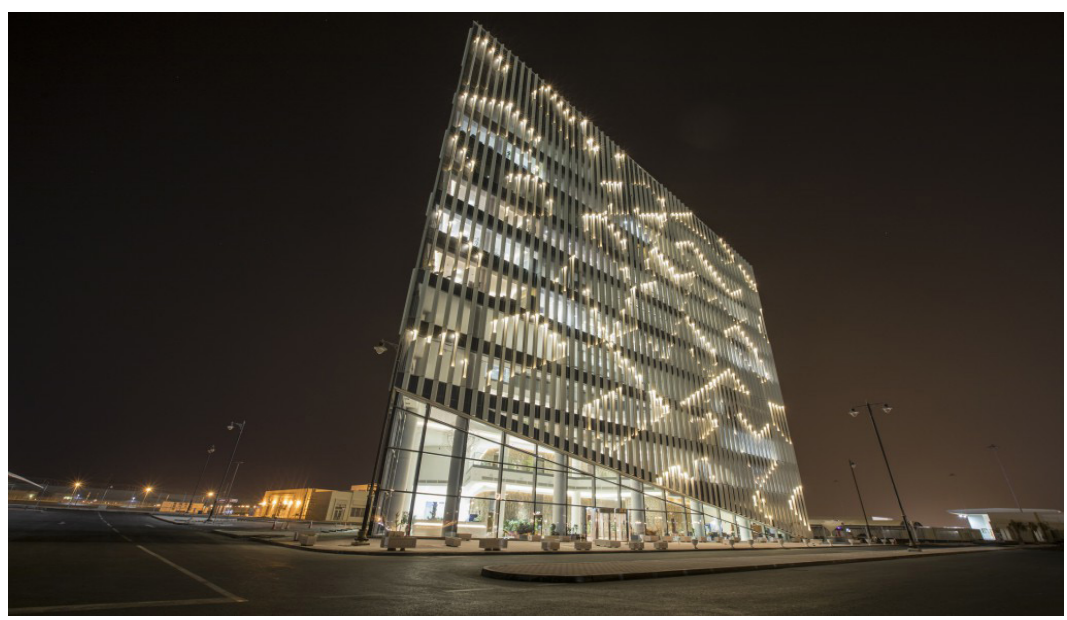

Figure 1: MWANI Qatar Building 
Hamad Port is a major green development; hence, distributed energy resources (DER) shall be one of the key sustainable addition for ports buildings. Thus, this paper will evaluate the benefits of adding a solar DER investment to MQ building being the face of the whole port development. The evaluation will include social and environmental aspects besides economic calculations outcome; in addition to the benefits of a battery storage to such investment.

\section{TRIPLE BOTTOM FRAMEWORK ANALYSIS, ECONOMIC FACTORS AND INVESTMENT REASONS}

The project economic factors will be assumed to be similar to a Commercial Building in Seattle, Washington USA. In this project, the cost of installation of the Solar PV panels is $2.4 \$ / \mathrm{W}$, which is based on the Barbose and Darghouth, Tracking the Sun 2018 Edition for large non-residential systems. Table 1 below shows the inputs used for the building calculations.

Table 1: Input summary

\begin{tabular}{|l|l|}
\hline Selected State for calculations & Washington \\
\hline Zip Code & 98101 \\
\hline Actual building location & Qatar \\
\hline Demand Charge & 20 \\
\hline Energy Charge & 0.12 \\
\hline CO2 & $0.3 \mathrm{lbs} / \mathrm{MWh}-0.0003 \mathrm{Ibs} / \mathrm{KWh}$ \\
\hline CO2 location & Washington, Seattle \\
\hline Solar & $2.4 \$$ /W \\
\hline Loan Duration & 10 years \\
\hline APR & $4 \%$ \\
\hline Federal ITC & $30 \%$ \\
\hline $\begin{array}{l}\text { Triple bottom line framework analysis } \\
\text { location }\end{array}$ & Qatar \\
\hline Utility Provider for calculations & Central Electric Networks (CEN) \\
\hline Utility provider for analysis basis & Kahramaa \\
\hline PV & Fixed Roof mounted \\
\hline PV & $250 \mathrm{KW}$ \\
\hline PV Watts location output & 98101 \\
\hline
\end{tabular}

The state of Qatar has established country goals represented in Qatar's 2030 vision that Hamad Port is a key investment leader in establishing those goals. Hamad Port is a strategic seaport that is one of the largest green projects in the region. During Hamad Port construction phase, there were major efforts to preserve the natural life, i.e., extensive plants relocation programs were established. Hamad Port Project was able to re-locate thousands of hard corals, soft corals, seagrasses, and mangrove trees. After relocation, the new locations were monitored and found out to have high rate of success, because the plants have grown as planned. In addition, the construction activities were environmentally controlled. Monitoring schemes have been implemented to ensure that the construction activities are following the set plan to preserve the environment. It is worth noting that Hamad Port buildings are designed following the energy conservation and sustainability requirements that all buildings have achieved the targeted ratings using 
the locally developed Global Sustainability Assessment System (GSAS), a sustainability rating system (Gulf Organization for Research \& Development, GORD). Adding solar panels to MQ building will further enhance Hamad port operations to follow the same environmental goal. Table 2 below shows the calculations outcome for the building before DER implantation and after, using Table $4 \&$ Table 5 monthly electricity consumption and associated costs.

Table 2: Economic results summary table

\begin{tabular}{|l|l|}
\hline LCOE of the facility (before PV) & $0.16 \$ / \mathrm{KWh}$ \\
\hline LCOE of the facility (with PV) & $0.245 \$ / \mathrm{KWh}$ \\
\hline LCOE of the PV & $0.192 \$ / \mathrm{KWh}$ \\
\hline Simple payback of the investment & 12.64 years \\
\hline Annual payment of the utility (before PV) & $47,586.17 \$ /$ year \\
\hline Annual Payment of the utility (with PV) & $14,368.65 \$ /$ year \\
\hline Expected production from PV array size & 269,676 \\
\hline Annual energy purchase from the utility (before PV) & $298,288 \mathrm{KWh} / \mathrm{yr}$ \\
\hline Annual energy purchase from the utility (with PV) & $28,612 \mathrm{KWh} / \mathrm{yr}$ \\
\hline Peak annual demand draw from the utility (before PV) & 57.6 \\
\hline Peak annual demand draw from the utility (with PV) & 48.6 \\
\hline CO2 emissions (before PV) & 89.5 \\
\hline CO2 emissions (after PV) & 8.6 \\
\hline Annual cost, if loan is considered & $51,782.2$ \\
\hline
\end{tabular}

The levelized cost of Energy (1COE) is a way to describe the present value of the solar investment by calculating the project break-even parameters. The LOCE can guide on which system to select when comparing conventional fuel systems with renewable system but it has a problem which shows in this project. The LCOE went after to 0.245 with PV because due to the simple calculation of LCOE, when you reduce energy and save money the LCOE goes up. In addition, LCOE ignores project risks and other social and environmental considerations.

The project has a recovery period (simple payback) for the PV investment of 12.64 years which is considered high if it is a private investment with profit goals. MQ is a governmental entity where the social and environmental benefits have higher weightage. As a matter of fact, MQ will be saving $\$ 33,217.5(47,586.17-14,368.65)$ of OPEX cost which is a great incentive. Moreover, the annual energy and the peak consumptions will be reduced by the PV usage, leading to the main investment reason which is an outstanding $96 \%$ lower $\mathrm{CO} 2$ emission.

In the light of the above, it would not be an exaggeration to say that the social aspect of reducing electricity usage by a clean zero emission energy source is intangible. Hamad 
Port covers a huge area of land of approximately $28 \mathrm{~km} 2$ and powering such development requires high energy sources. The main energy provider in Qatar is Kahramaa and their power generation comes from fossil fuel sources. Kahramaa has implemented a program called "Tarsheed" that aims to reduce 7\% of harmful carbon emissions in Qatar. (AlKuwari, 2018). Adding Solar PV will reduce energy consumption, and CO2 emission will be reduced by $96 \%$ as calculated which is an important addition to the green port goal and Tarsheed program as well. Adding solar PV satisfies both the environmental sector by lower GHG emissions and the social sector by providing better atmosphere without compromising stable electricity supply.

In other words, such investments are built to show Qatar's efforts following the future vision of clean, developed and environmentally friendly nation.

\section{TECHNOLOGY}

The weather in Qatar is clear most of the year and Hamad Port is quite far from the city or any populated area and there are no towers or adjacent high-rise buildings to obstruct the sun. Thus, the proposed PV panels are flat fixed panels to maximize the sun exposure and will be placed on the roof of the building. Movable tracking panels will add extra burden on the budget and will not create a huge difference in the local weather conditions.

Kahramaa, the electricity provider in Qatar, does not accept power return to the network; unlike the USA ("Washington State Department of Commerce" \& "Net Metering."). This is a major point to consider during the design and planning of this project that extra power cannot be utilized, unless there is a well-established storage system. The power generated by the PV panels shall be consumed $100 \%$ within the building; accordingly, the solar PV system was designed to be consumed 100\% within the building.

Solar PV panels are quite a new technology in Qatar and there are limited options of suppliers with local experience and local availability to operate the system. To gain the best outcome possible of the PV panels, the same technology that was used in Mshereib Downtown project (MDD) will be considered. The reason behind this selection is that, Msheeib properties, the developer of MDD, is a semi-governmental entity and the selection process follows the same tendering rules as MQ. In addition, the procurement process in a government related project ranges between 6 to 9 months to be able to award a single package because the process should go through tender, technical and steering committees followed by the prime minister's endorsement. Qatar is quite a small country and the delegation of authority is limited to QAR100,000 for project directors. MDD design was well studied and any similar study will most likely yield the same outcomes; the technology and its supporting parameters have been evaluated in a detailed manner allowing the best efficiency possible for the local environment.

As a result, the technology proposed is KIOTO PV model KPV PE NEC 240WP along with SMA solar Technology AG inverter model Sunny Tripower. The system has a maxium power output of $265 \mathrm{Wp}$ with $15.7 \%$ panel efficiency and a very high operating temperature range reaching $85{ }^{\circ} \mathrm{C}$. The Panel dimensions are $1700 \mathrm{Hx} 995 \mathrm{Wx} 7 \mathrm{D} \mathrm{mm}$ with Polycrystalline cell type 156x156 mm. 


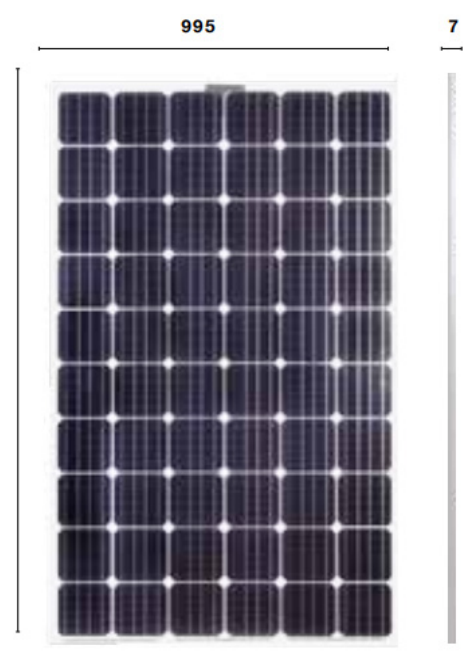

7 Figure 2 shows KIOTO PV panel sample ("ENF Solar"); the project panels are designed to have 3 bypass diodes to reduce the loss and is selected to be poly-crystalline to be more efficient for Qatar's hot weather. The mounting structure is built by HILTI which has a local supplier. As of any design, technology is always meant to deliver the best possible outcome; however, in this project, designers were concerned to not exceed the peak usage of electricity at any point of the day. The proposed technology will be using several locally available equipment to minimize future operational matters with a design that is operated and maintained locally.

Figure 2: KIOTO PV model KPV

\section{BATTERY STORAGE}

Battery storage is a great addition to the solar energy system; it adds many additional benefits and features. However, storage system has great challenges of how the facility is planning to use it. In other words, controlling the storage battery system is the main factor that drives all features. For instance, if the batteries are not charged when they need to be used, then their great value will be lost. The better the facility controls the storage, the higher the values and benefits. For this project, battery storage control strategies are assumed to be well planned and implemented to optimize the system outcome. Table 3 below shows the benefits of adding solar PV source and their possible effect rate on the building.

Table 3: benefits of adding solar PV to MQ building

\begin{tabular}{|l|c|}
\hline Value & Effect \\
\hline Retail Electric Energy Time-shift & High \\
\hline Demand charge management & High \\
\hline Resiliency & Low \\
\hline Electric supply capacity \& Independence & Low \\
\hline Reserve Power for emergencies & Low \\
\hline Kahramaa Power return prevention & High \\
\hline
\end{tabular}

Note: There are many other benefits that were neglected due to the project nature and location. For instance, voltage support which does not apply in Qatar grid

\subsection{Retail electric energy time-shift}

It involves the storage used to reduce the energy usage and eventually reducing the overall cost of the electricity. The peak time electricity charges are higher than off-peak charges, and the storage can be used to reduce electricity usage during the peak time 
of the day while charging during off peak time. Doing so, will result in less cost to the utility by reducing the energy bought from the provider. Accordingly, this is a high relevant value to this project.

The utility calculation of adding a solar PV system resulted in a reduction of energy usage, which is equivalent to $\$ 33,217.52$.

\subsection{Demand charge management}

Each facility is being charged for energy usage as well as peak load. Battery storage can add high value to the building by reducing the peak load values that it uses. For this project, the peak load is reduced adding a saving off $\$ 856.44$ dollars to the bill. Moreover, with battery storage the saving will be much higher by reducing peak loads.

\subsection{Resiliency}

Qatar weather is stable throughout the year with minimal rain, wind or natural disasters. This value is considered because in the past few years, Qatar has experienced few days with heavy rain and high-speed wind that were not expected or designed for. Those unusual days resulted in electric outages to many areas around the city. Figure 3 below shows Doha city floods due to excess rain that the drainage system was not designed for.

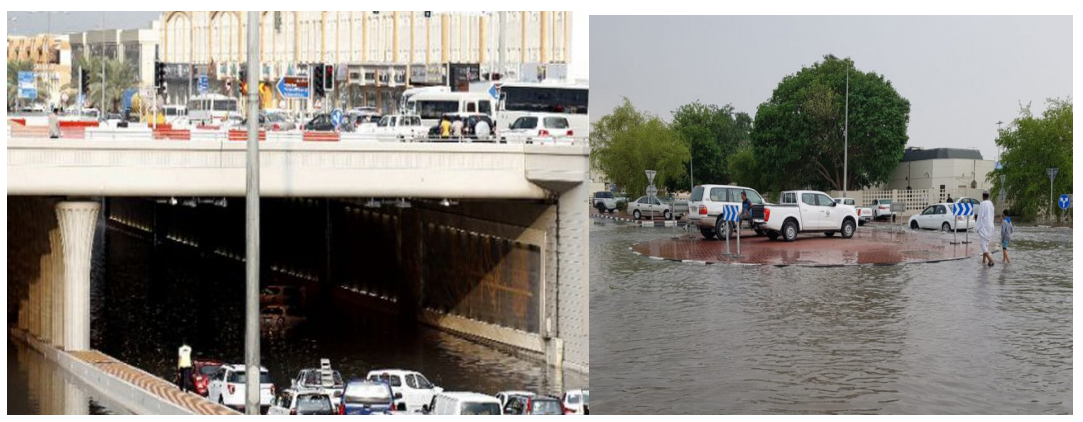

Figure 3: Heavy rain effect (Qatar)

The probability of such incidents is low but its impact is huge; storage system will add great benefit to the facility in such incidents. This is considered to be a low added value to the system because the government has been implementing great measures to upgrade the drainage and storm water systems to minimize the impact of natural disasters.

\subsection{Electric supply capacity \& Independence}

Due to the fact that Hamad Port is a huge area isolated from the city, the electric system design was built with a number of substations to be located around the port area to provide power for allocated areas/buildings. Hamad Port has approximately two major substations distributing the power to 9 smaller substations. As the port is a major development in Qatar, the government added a visitor's center with aquarium after project completion. Adding such a huge building in the electricity grid resulted in an electric shortage and a new substation had to be built. Electric storage can be used to reduce the need to build additional substations, by implementing a well-designed 
and controlled storage system, significant energy usage could be reduced in which MQ building can be a valid case to initiate green energy usage.

In addition to the above, Hamad port could eventually reach independence from the grid with vast empty areas that can be utilized for green power. MQ building can be a case study building as well to achieve the independence out of the system and adding a battery storage could make this possible.

\subsection{Reserve Power for emergencies}

Qatar designed codes and civil defense regulations require each building (or substations) providing power to have a backup generator available to be used during blackout or power issues. Adding a battery storage system, can save the facility, the generators cost and the associated fuel cost. In general, a diesel backup generator from Cummins, the unified brand used at the port, costs approximately US\$100,000 due to distinct port specifications that generators have to be sea corrosion coated with high temperature working environment specs. This cost is another added incentive to the storage system.

In addition, replacing the backup generator with a battery storage system will reduce $\mathrm{CO} 2$ emission leading to social and health benefits besides the environmental benefits.

\subsection{Kahramaa Power return prevention}

As mentioned above, Kahramaa does not allow power return to the grid in case of any excess power produced that the design had to be changed in order to account for such restriction. Adding a storage system, will eliminate such restriction in which the PV power could be increased, and further savings could be achieved. In some cases, a zero PV system could be added that could result in almost zero payment for electricity (excluding meter cost) because Qatar does not have a taxation system.

\section{CONCLUSION}

Hamad Sea Port (HP) is one of the biggest projects in the region that is mainly built to serve Qatar 2022 World Cup needs and is considered one of the key projects in Qatar 2030 Vision. Mwani Qatar (MQ) is responsible for the management and operations of HP and is considered the front face of HP's image. Adding a distributed renewable energy (DER) investment for the MQ building is considered a great overall investment that will not only save energy usage, but will yield benefits to all sectors of economics, society and environment.

The proposed DER is a solar PV system that has $250 \mathrm{KW}$ output. The considered system will use the flat fixed KIOTO PV panels connected to a SMA solar Technology AG inverter model. This type of technology was proven to be effective and locally applicable in a similar mega governmental project, Mshereib Downtown (MDD). The technology and its supporting parameters have been evaluated in a detailed manner allowing the best efficiency possible for the local environment.

A Battery Energy Storage System (BESS) can add many benefits to the solar PV system that makes the investment more appealing for decision makers. The BESS will save bill charges by shifting electric energy consumption out of the peak time and will reduce the peak usages of the facility. Also, it will add reliability and power reserve to 
the system during disasters and emergencies. BESS will open the ability to increase the PV output as the excess energy output can be stored creating a further possibility of a stand-alone facility option to be further considered in the future.

In the light of the above, the solar PV investment calculations shown in Tables 2, $4 \& 5$ indicate savings of $\$ 33,217.52$ to the facility leaving a stronger overall impact towards the environmental and social benefits. The $\mathrm{CO} 2$ reduction is $96 \%$, which is a great start for a small nation like Qatar. Also, this project will add to the environmental requirements dictated by the Ministry of Municipality and Environment (MME) and the energy saving design developed by Global Sustainability Assessment System (GSAS) sustainability rating. As a matter of fact, Qatar is a small rich country and even if the investment did not reach the needed cost saving parameters, the social aspects with their environmental benefits are always more valuable to the country's objectives and goals. The solar PV system for MQ building is a great addition to the ongoing governmental path towards a clean, modern and sustainable nation.

\section{APPENDIX}

Table 4: Facility without DER

\begin{tabular}{|c|c|c|c|c|c|c|}
\hline \multicolumn{2}{|r|}{ Month } & $\begin{array}{c}\text { Peak demand } \\
(k W)\end{array}$ & $\begin{array}{c}\text { Monthly energy } \\
\text { (kWh) }\end{array}$ & $\begin{array}{c}\text { Demand } \\
\text { charge (\$) }\end{array}$ & $\begin{array}{c}\text { Energy } \\
\text { charge (\$) }\end{array}$ & $\begin{array}{c}\text { Total utility } \\
\text { bill (\$) }\end{array}$ \\
\hline 1 & January & 45.8 & 25,348 & $\$ 916.96$ & $\$ 3,041.74$ & $\$ 3,958.69$ \\
\hline 2 & February & 46.6 & 22,728 & $\$ 931.35$ & $\$ 2,727.40$ & $\$ 3,658.76$ \\
\hline 3 & March & 45.9 & 24,994 & $\$ 917.93$ & $\$ 2,999.28$ & $\$ 3,917.21$ \\
\hline 4 & April & 51.4 & 24,168 & $\$ 1,028.10$ & $\$ 2,900.21$ & $\$ 3,928.31$ \\
\hline 5 & May & 48.5 & 24,890 & $\$ 970.23$ & $\$ 2,986.80$ & $\$ 3,957.03$ \\
\hline 6 & June & 51.5 & 24,256 & $\$ 1,030.18$ & $\$ 2,910.66$ & $\$ 3,940.84$ \\
\hline 7 & July & 54.6 & 25,775 & $\$ 1,092.74$ & $\$ 3,093.02$ & $\$ 4,185.77$ \\
\hline 8 & August & 57.6 & 26,456 & $\$ 1,152.01$ & $\$ 3,174.70$ & $\$ 4,326.71$ \\
\hline 9 & September & 49.0 & 24,565 & $\$ 979.35$ & $\$ 2,947.82$ & $\$ 3,927.18$ \\
\hline 10 & October & 46.1 & 25,181 & $\$ 922.05$ & $\$ 3,021.68$ & $\$ 3,943.72$ \\
\hline 11 & November & 46.7 & 24,514 & $\$ 933.64$ & $\$ 2,941.63$ & $\$ 3,875.27$ \\
\hline 12 & December & 45.9 & 25,413 & $\$ 917.10$ & $\$ 3,049.58$ & $\$ 3,966.68$ \\
\hline \multicolumn{2}{|c|}{$\begin{array}{l}\text { ANNUAL } \\
\text { VALUE }\end{array}$} & 57.6 & 298,288 & $\$ 11,791.64$ & $\$ 335,794.53$ & $\mathbf{\$ 4 7 , 5 8 6 . 1 7}$ \\
\hline
\end{tabular}

Table 5: Facility calculations with PV

\begin{tabular}{|c|c|c|c|c|c|c|}
\hline \multicolumn{2}{|r|}{ Month } & \multirow{2}{*}{$\begin{array}{c}\begin{array}{c}\text { Peak demand } \\
(\mathrm{kW})\end{array} \\
45.8 \\
\end{array}$} & \multirow{2}{*}{$\begin{array}{c}\begin{array}{c}\text { Monthly energy } \\
(\mathbf{k W h})\end{array} \\
\mathbf{1 5 , 9 8 9} \\
\end{array}$} & \multirow{2}{*}{$\begin{array}{c}\begin{array}{c}\text { Demand } \\
\text { charge (\$) }\end{array} \\
\$ 916.96 \\
\end{array}$} & \multirow{2}{*}{$\begin{array}{c}\begin{array}{c}\text { Energy } \\
\text { charge }(\$)\end{array} \\
\$ 1,918.67 \\
\end{array}$} & \multirow{2}{*}{$\begin{array}{c}\begin{array}{c}\text { Total utility } \\
\text { bill (\$) }\end{array} \\
\$ 2,835.63 \\
\end{array}$} \\
\hline 1 & January & & & & & \\
\hline 2 & February & 46.6 & 8,561 & $\$ 931.35$ & $\$ 1,027.30$ & $\$ 1,958.65$ \\
\hline 3 & March & 45.9 & 4,691 & $\$ 917.93$ & $\$ 562.91$ & $\$ 1,480.84$ \\
\hline 4 & April & 45.4 & $(4,440)$ & $\$ 908.65$ & $(\$ 532.85)$ & $\$ 375.81$ \\
\hline 5 & May & 43.4 & $(6,475)$ & $\$ 868.46$ & (\$777.05) & $\$ 91.40$ \\
\hline 6 & June & 40.8 & $(9,229)$ & $\$ 816.54$ & $(\$ 1,107.50)$ & $(\$ 290.96)$ \\
\hline 7 & July & 43.6 & $(10,261)$ & $\$ 872.87$ & $(\$ 1,231.34)$ & (\$358.47) \\
\hline 8 & August & 48.0 & $(6,826)$ & $\$ 959.02$ & $(\$ 819.14)$ & $\$ 139.87$ \\
\hline 9 & September & 48.6 & $(1,664)$ & $\$ 971.31$ & $(\$ 199.62)$ & $\$ 771.69$ \\
\hline 10 & October & 46.1 & 8,068 & $\$ 921.37$ & $\$ 968.14$ & $\$ 1,889.51$ \\
\hline 11 & November & 46.7 & 13,319 & $\$ 933.64$ & $\$ 1,598.26$ & $\$ 2,531.91$ \\
\hline 12 & December & 45.9 & 16,881 & $\$ 917.10$ & $\$ 2,025.66$ & $\$ 2,942.76$ \\
\hline & $\begin{array}{l}\text { ANUAL } \\
\text { VALUE }\end{array}$ & 48.6 & 28,612 & $\$ 10,935.20$ & $\$ 3,433.45$ & $\$ 14,368.65$ \\
\hline
\end{tabular}




\section{REFERENCES}

Al-Kuwari, Essa (2018). Kahramaa set to award solar power plant tender. Gulf Times, 7 Oct. 2018. Retrieved from http://www.gulf-times.com/story/608567/Kahramaa-set-to-awardsolar-power-plant-tender.

Energy Independence Act (EIA or I-937). Washington State Department of Commerce. Retrieved from www.commerce.wa.gov/growing-the-economy/energy/energy-independence-act/.

ENF Ltd. "ENF Ltd." ENF Solar. Retrieved from www.enfsolar.com/pv/panel-datasheet/ crystalline/35193.

GSAS: Global Sustainability Assessment System. GulfOrganization for Research \& Development (GORD). Retrieved from http://www.gord.qa/gsas-trust.

Mwani Qatar. About Us - Mwani Qatar - Rising to the Challenge. MwaniQatar. Retrieved from https://www.mwani.com.qa/English/AboutUs/Pages/default.aspx.

"Net Metering” (2016). Washington Utilities and Transportation Commission. Retrieved from https://www.utc.wa.gov/regulatedIndustries/utilities/energy/Pages/netMetering.aspx.

Steering Committee, New Port Project. “Investing in Qatar's Future.” New Port Project. Retrieved from http://www.npp.com.qa/overview.html. 